\title{
Elite selection of tagasaste (Chamaecytisus palmensis) for drought- prone sites
}

\author{
G.B. DOUGLAS, D.R. WOODFIELD and A.G. FOOTE \\ AgResearch Grasslands, Private Bag 11008, Palmerston North
}

\begin{abstract}
Tagasaste (tree lucerne) is a drought-tolerant, shrub/ tree legume which is naturalised in many parts of New Zealand. It is a potentially useful supplementary forage for sheep and cattle, particularly in summer and early autumn. Tagasaste is highly variable for a range of attributes and in the 1980s, 16 lines were identified which had improved production, habit, and frost and disease tolerance. From 1993 to 1996, this germplasm was evaluated for morphological and chemical attributes at two sites in the lower North Island - Onga Onga, central Hawke's Bay (Trial 1) and Bulls, Rangitikei (Trial 2) - to select material for release. Differences in survival and growth of the lines between sites were the major finding. Average plant survival of lines in Trial 1 was higher than in Trial 2 (89 vs 58\%), whereas growth of lines in Trial 2 exceeded that in Trial 1, for example for plant height (274 vs 168 $\mathrm{cm})$, plant width (325 vs $168 \mathrm{~cm})$, root collar diameter ( $91 \mathrm{vs} 58 \mathrm{~mm}$ ) and total plant dry matter ( $15.6 \mathrm{vs} 6.7 \mathrm{~kg} / \mathrm{plant})$. The total $\mathrm{N}$ content of lines in Trial 2 was $25 \%$ higher than in Trial 1 (33 vs 26 $\mathrm{g} \mathrm{N} / \mathrm{kg} \mathrm{DM}$ ) whilst in vitro digestibility of herbage from all lines at each site was $75 \%$. Two lines, AL2244 and AL2432, which had high survival at both sites, and means for other attributes which were similar to or exceeded the site mean for all lines, were selected to comprise the final release. Seed of these lines is being increased.
\end{abstract}

Keywords: browse shrubs, Chamaecytisus palmensis, drought fodder, dryland legumes, revegetation, selection

\section{Introduction}

Tagasaste (Chamaecytisus palmensis (Christ) Hutch.), formerly known as tree lucerne, is a fast-growing, perennial, evergreen, leguminous tree, 5-6 $\mathrm{m}$ tall when mature, which is widely distributed throughout New Zealand (Woodfield \& Forde 1987). It originates from the island of La Palma in the Canary Islands, and probably arrived in New Zealand from seeds distributed late last century or early this century.
For almost two decades, there has been interest in tagasaste as a potential source of supplementary feed in drought-prone environments. Tagasaste produces good dry matter (DM) yields and is acceptable to sheep, cattle and goats. Its leaves have a nitrogen $(\mathrm{N})$ content of 25-40 g N/kg DM and in vitro/in vivo DM digestibility levels normally exceed 70\% (Lambert et al. 1989b; Douglas et al. 1996). An advantage during drought is the ability of the species to retain green leaf for 3-5 months, much longer than for temperate grasses and legumes (Borens \& Poppi 1990). Tagasaste is susceptible to frost damage (Sheppard \& Bulloch 1986), particularly when young, which restricts its potential widespread usefulness to drought-prone areas, probably in Canterbury and northwards in the South Island, and most places in the North Island, except for the Central Plateau.

There is considerable genetic variation within and between populations of tagasaste for a range of morphological attributes, including production and growth habit. Accordingly, in the early to mid 1980s, a breeding programme was initiated at Palmerston North to develop lines of tagasaste with improved production, habit, and frost and disease tolerance (Woodfield \& Forde 1987). This resulted in 16 elite lines which were established in 1993 at two lower North Island sites, to determine their suitability for release. This paper summarises the results of these evaluations and identifies the final selection.

\section{Materials and methods}

\section{Sites}

Both trials were conducted on commercial farms. Trial 1 was on cultivated flat land at Onga Onga, central Hawke's Bay on a stony silt loam $(\mathrm{pH}=6.9$, Olsen $\mathrm{P}=$ $53 \mathrm{mg} / \mathrm{kg}$ soil, $\mathrm{S}_{\left(\mathrm{SO}_{4}\right)}=6 \mathrm{mg} / \mathrm{kg}$ soil), which is subject to moderate to severe wind erosion, when vegetation cover is sparse. Trial 2 was on a $<10^{\circ}$ north-westerly face at Bulls in Rangitikei on former erodible coastal sand dune country $(\mathrm{pH}=7.4$, Olsen $\mathrm{P}=41 \mathrm{mg} / \mathrm{kg}$ soil, $\mathrm{S}\left(\mathrm{SO}_{4}\right)=3 \mathrm{mg} / \mathrm{kg}$ soil), approximately $140 \mathrm{~km}$ from Trial 1 and $12 \mathrm{~km}$ from the sea. Resident pasture was dominated by assorted grasses and flatweeds, which were sprayed with glyphosate $(1.1 \mathrm{~kg} / \mathrm{ha})$ and dicamba $(0.4 \mathrm{~kg} / \mathrm{ha}) 4$ weeks before planting. Both sites are 
prone to significant summer soil moisture deficits, and have free-draining soils.

\section{Lines, plant preparation and experimental design}

Seedlings of the 16 lines (Table 1) were prepared in the glasshouse in autumn/winter 1993, including inoculation with an effective Rhizobium strain (Douglas et al. 1996), and transplanted into the trial sites in September/October 1993. Trials comprised 3 (Trial 2) or 4 (Trial 1) randomised complete blocks, and each plot (experimental unit) consisted of a single row of 6 plants. Plant spacing was $1.5 \times 4.0 \mathrm{~m}$ within and between rows, respectively, equivalent to 1670 plants/ha. Both trials were fenced to exclude rabbits. In late April 1994, all plants were cut to $50 \mathrm{~cm}$ height above ground, to encourage branching. Surrounding pasture was mown and sprayed (glyphosate at $1.1 \mathrm{~kg} / \mathrm{ha}+$ simazine at $1.0 \mathrm{~kg} / \mathrm{ha}$ ) periodically throughout the evaluations to minimise competition with the trees.

Table 1 Lines of Chamaecytisus palmensis evaluated in two trials in the lower North Island from 1993-96.

\begin{tabular}{|c|c|}
\hline Line/Plant $^{1}$ & Description $^{2}$ \\
\hline AL1943/220 & Umere ${ }^{3}$ \\
\hline AL2168/561 & Totaranui, Abel Tasman National Park introduction \\
\hline AL2244/179 & $\begin{array}{l}\text { 'Auchenflower', Darfield ex T5 elite plant (AL1941/ } \\
910)\end{array}$ \\
\hline AL2258/555 & Ormand, Gisborne introduction \\
\hline AL2286/427 & Rewa, ex T5 elite plant (AL1993/130) \\
\hline AL2301/364 & Umere, ex T5 elite plant (AL1943/220) \\
\hline AL2370/228 & $\begin{array}{l}\text { Southern Hawke's Bay, ex T5 elite plant (AL1980/ } \\
806)^{4}\end{array}$ \\
\hline AL2432/233 & Napier, ex T5 elite plant (AL1917/1123) \\
\hline AL2528/164 & Greymouth root rot resistant introduction \\
\hline AL2541/357 & Kaikohe introduction \\
\hline AL2701/227 & Brandy Creek, Wakefield introduction \\
\hline AL2723/059(a) & Te Uri, ex T4 clonal block \\
\hline AL2723/456(b) & Te Uri, ex T4 clonal block \\
\hline AL2724/269 & Pukekohe, ex T4 clonal block \\
\hline AL2725/144 & 'Auchenflower', Darfield ex T4 clonal block \\
\hline AL2726/329 & Margot's Green, ex T4 clonal block \\
\hline
\end{tabular}

${ }^{1}$ Line numbers are those allocated in the Margot Forde Forage Germplasm Centre, Palmerston North; ${ }^{2}$ Place names refer to the original collection sites, $\mathrm{T}$ numbers refer to blocks at AgResearch, Palmerston North; ${ }^{3}$ Trial 1 only; ${ }^{4}$ Trial 2 only

\section{Assessments}

Plants were assessed from 1993 to 1996 for numerous attributes including survival (\%), maximum height ( $\mathrm{mm})$ and width (mm), extent of branching (score 1 (low) to 3 ), vigour (score 1 (low) to 5), canopy density (score 1 (low) to 5), root collar diameter (mm), edible and total dry matter (DM) yield (kg DM/plant), leaf content (\%), and growth stage (vegetative, flowering, pods). On 20 21 April 1994, edible foliage (leaf + stem $<3 \mathrm{~mm}$ diameter) of lines at each site was sampled, freezedried, and ground to pass through a $1 \mathrm{~mm}$ aperture sieve for laboratory analyses. Samples were analysed for total nitrogen $(\mathrm{N})$ content $(\mathrm{g} \mathrm{N} / \mathrm{kg} \mathrm{DM})$ by combustion, reduction to elemental $\mathrm{N}$ and detection by thermal conductivity in a Carlo Erba (Milan, Italy) auto analyser, and in vitro DM digestibility (g DM/kg DM) by a twostage pepsin/cellulase technique (McLeod \& Minson 1976) using Onozuka 3 S cellulase (McLeod \& Minson 1980). The nutritional data and selected assessment results from 1995/96 are presented.

\section{Statistical analyses}

Data for each attribute were analysed by analysis of variance for a randomised complete block design (Steel \& Torrie 1980), using the PROC GLM procedure in SAS (1988). For the 14 lines evaluated at both sites (Table 1), analyses of variance pooled over sites were also conducted to test the significance of differences between sites and between lines, and their interaction. Probabilities $(\mathrm{P})$ of significance tests were classified as NS $(\mathrm{P}>0.05),{ }^{*}(\mathrm{P}<0.05)$, and ** $(\mathrm{P}<0.01)$.

\section{Results}

\section{Morphology and forage yield}

Trial 1: There were significant differences between lines for three of the ten attributes assessed quantitatively, namely plant vigour in December 1995 and February 1996, and canopy density (Table 2). Plant survival after approximately 2 years exceeded $80 \%$ for all lines, except for AL2723, which was $60 \%$. Maximum average height and width were similar for all lines and average plant vigour score in February was slightly higher than in December. However the lines at both times exhibited only occasional leaf chlorosis and wilting/rolling, except for AL1943 which had leaf tip necrosis on some plants, suggesting slight drought stress. Lines AL2244 and AL2432 had "near perfect" vigour in February. All lines were predominantly vegetative in December, apart from AL2244 which had pods on most plants. Across the 15 lines, edible DM/plant in March 1996 was similar, ranging from 19.6 to $22.4 \%$ of total plant DM.

Trial 2: Plant survival and growth were not significantly different $(\mathrm{P}>0.05)$ between lines (Table 3$)$ although across lines there was over a two-fold variation in survival (40-93\%) (Table 3). Maximum plant width exceeded height by $50 \mathrm{~cm}$ and most lines had similar vigour in December 1995 and February 1996. For all lines, plants with pods were most prevalent in December. In March 1996, edible DM/plant ranged from 10.1 to $12.4 \%$ of total plant DM for the 15 lines.

Between-trial comparisons: Lines in Trial 1 had higher plant survival (89 vs $58 \%$; $\mathrm{P}<0.05$ ) and their canopies were more highly branched $(2.7$ vs $2.2 ; \mathrm{P}<0.01)$ than 
Table 2 Survival and growth of 15 lines of Chamaecytisus palmensis in Trial 1 at Onga Onga, central Hawke's Bay in 1995/96.

\begin{tabular}{|c|c|c|c|c|c|c|c|c|c|c|c|}
\hline Line & $\begin{array}{c}\text { Survival } \\
(\%)\end{array}$ & $\begin{array}{l}\text { Height } \\
(\mathrm{cm})\end{array}$ & $\begin{array}{l}\text { Width } \\
(\mathrm{cm})\end{array}$ & ${ }^{1}$ Vigour & $\begin{array}{l}{ }^{2} \text { Canopy } \\
\text { Density }\end{array}$ & $\begin{array}{l}{ }^{3} \mathrm{RCD} \\
(\mathrm{mm})\end{array}$ & $\begin{array}{l}{ }^{4} \text { Reproductive } \\
\text { development }\end{array}$ & Vigour & ${ }^{5}$ Branching & $\begin{array}{l}\text { Total dry } \\
\text { weight } \\
\text { (kg/plant) }\end{array}$ & $\begin{array}{c}\text { Total edible } \\
\text { dry weight } \\
\text { (kg/plant) }\end{array}$ \\
\hline & $14 / 12 / 95$ & $14 / 12 / 95$ & $14 / 12 / 95$ & $14 / 12 / 95$ & $14 / 12 / 95$ & $14 / 12 / 95$ & $14 / 12 / 95$ & $22 / 02 / 96$ & $22 / 02 / 96$ & $20 / 03 / 96$ & $20 / 03 / 96$ \\
\hline AL1943 & 85 & 151 & 139 & 3.3 & 3.1 & 46 & V,F,P & 4.5 & 2.4 & 5.6 & 1.1 \\
\hline AL2168 & 95 & 175 & 171 & 3.9 & 4.2 & 64 & $\mathrm{~V}, \mathrm{~F}, \mathrm{P}$ & 4.5 & 2.8 & 8.4 & 1.7 \\
\hline AL2244 & 95 & 178 & 174 & 4.2 & 4.1 & 67 & $\mathbf{P}, \mathrm{V}, \mathrm{F}$ & 4.9 & 2.9 & 7.2 & 1.5 \\
\hline AL2258 & 95 & 184 & 178 & 4.2 & 3.8 & 63 & $\mathbf{V}, \mathrm{F}, \mathrm{P}$ & 4.6 & 2.8 & 8.0 & 1.6 \\
\hline AL2286 & 85 & 156 & 163 & 3.9 & 3.8 & 49 & $\mathbf{V}, \mathrm{F}, \mathrm{P}$ & 4.3 & 2.4 & 6.2 & 1.3 \\
\hline AL2301 & 100 & 166 & 187 & 3.6 & 4.1 & 57 & $\mathbf{V}, \mathrm{F}, \mathrm{P}$ & 4.5 & 2.9 & 6.3 & 1.3 \\
\hline AL2432 & 95 & 180 & 185 & 4.2 & 4.2 & 60 & $V, F, P$ & 4.8 & 2.8 & 7.6 & 1.6 \\
\hline AL2528 & 85 & 159 & 155 & 3.8 & 3.7 & 55 & V,F,P & 4.1 & 2.3 & 6.0 & 1.2 \\
\hline AL2541 & 90 & 164 & 169 & 3.9 & 4.1 & 65 & $\mathbf{V}, \mathrm{F}, \mathrm{P}$ & 4.6 & 2.4 & 6.5 & 1.4 \\
\hline AL2701 & 80 & 168 & 160 & 4 & 3.5 & 56 & $\mathrm{~V}, \mathrm{P}$ & 4.4 & 2.6 & 6.4 & 1.3 \\
\hline AL2723a & 60 & 184 & 182 & 3.7 & 4.2 & 61 & $\mathbf{V}, \mathrm{F}, \mathrm{P}$ & 4.7 & 2.8 & 7.1 & 1.4 \\
\hline AL2723b & 85 & 153 & 151 & 3.7 & 3.8 & 54 & $\mathrm{~V}, \mathrm{~F}, \mathrm{P}$ & 4.2 & 2.8 & 6.9 & 1.4 \\
\hline AL2724 & 95 & 155 & 160 & 3.8 & 3.8 & 58 & $\mathrm{~V}, \mathrm{P}$ & 4.3 & 2.7 & 5.8 & 1.3 \\
\hline AL2725 & 90 & 171 & 169 & 3.8 & 3.7 & 59 & $\mathbf{V}, \mathrm{P}$ & 4.7 & 2.6 & 6.3 & 1.3 \\
\hline AL2726 & 95 & 169 & 173 & 3.9 & 3.9 & 60 & $\mathrm{~V}, \mathrm{~F}, \mathrm{P}$ & 4.5 & 2.7 & 6.7 & 1.4 \\
\hline mean & 89 & 168 & 168 & 3.9 & 3.9 & 58 & & 4.5 & 2.7 & 6.7 & 1.4 \\
\hline Signif & NS & NS & NS & ** & * & NS & & * & NS & NS & NS \\
\hline
\end{tabular}

${ }^{1}$ scored 1 (poor) to 5 (near perfect); ${ }^{2}$ scored 1 (low) to 5 (high); ${ }^{3}$ root collar diameter; ${ }^{4} \mathrm{~V}=$ vegetative, $F=$ flower, $\mathrm{P}=$ pods (most frequent occurrence in bold); ${ }^{5}$ scored 1 (low) to 3 (high); final selections indicated by shading

Table 3 Survival and growth of 15 lines of Chamaecytisus palmensis in Trial 2 at Bulls, Rangitikei in 1995/96.

\begin{tabular}{|c|c|c|c|c|c|c|c|c|c|c|c|}
\hline Line & $\begin{array}{c}\text { Survival } \\
(\%)\end{array}$ & $\begin{array}{l}\text { Height } \\
(\mathrm{cm})\end{array}$ & $\begin{array}{l}\text { Width } \\
(\mathrm{cm})\end{array}$ & 1Vigour & $\begin{array}{l}{ }^{2} \text { Canopy } \\
\text { Density }\end{array}$ & $\begin{array}{l}{ }^{3} \mathrm{RCD} \\
(\mathrm{mm})\end{array}$ & $\begin{array}{l}{ }^{4} \text { Reproductive } \\
\text { development }\end{array}$ & Vigour & ${ }^{5}$ Branching & $\begin{array}{l}\text { Total dry } \\
\text { weight } \\
\text { (kg/plant) }\end{array}$ & $\begin{array}{c}\text { Total edible } \\
\text { dry weight } \\
\text { (kg/plant) }\end{array}$ \\
\hline & $13 / 12 / 95$ & $13 / 12 / 95$ & $13 / 12 / 95$ & $13 / 12 / 95$ & $13 / 12 / 95$ & $13 / 12 / 95$ & $13 / 12 / 95$ & $28 / 02 / 96$ & $28 / 02 / 96$ & 06/03/96 & 06/03/96 \\
\hline AL2168 & 73 & 254 & 289 & 4.1 & 3.3 & 87 & $\mathbf{P}$ & 4.3 & 2.5 & 10.9 & 1.1 \\
\hline AL2244 & 80 & 280 & 297 & 4.2 & 3.3 & 81 & $\mathbf{P}, \mathbf{V}$ & 4.3 & 1.8 & 15.4 & 1.8 \\
\hline AL2258 & 53 & 290 & 312 & 4.1 & 3 & 81 & $\mathbf{P}$ & 4.4 & 2.1 & 18.4 & 2.2 \\
\hline AL2286 & 47 & 245 & 316 & 3.9 & 3.3 & 87 & $\mathbf{P}$ & 4.1 & 2.3 & 11.9 & 1.2 \\
\hline AL2301 & 53 & 220 & 312 & 4.4 & 4 & 108 & $\mathbf{P}$ & 4.5 & 2 & 15.5 & 1.8 \\
\hline AL2370 & 53 & 265 & 322 & 4.5 & 3.6 & 97 & $\mathbf{P}$ & 4.8 & 2.8 & 14.3 & 1.6 \\
\hline AL2432 & 93 & 264 & 330 & 4.4 & 3.4 & 86 & $\mathbf{P}$ & 4.6 & 2.1 & 14.7 & 1.7 \\
\hline AL2528 & 60 & 311 & 407 & 4.8 & 3.7 & 108 & $\mathbf{P}$ & 4.7 & 2 & 21.7 & 2.7 \\
\hline AL2541 & 60 & 264 & 325 & 4.2 & 3.3 & 80 & $\mathbf{P}, \mathbf{V}$ & 4.4 & 1.7 & 15.9 & 1.9 \\
\hline AL2701 & 47 & 285 & 249 & 4.1 & 3.3 & 85 & $\mathbf{P}$ & 4.4 & 2 & 17.8 & 2.2 \\
\hline AL2723a & 40 & 320 & 342 & 3.8 & 3.2 & 92 & $\mathbf{P}$ & 4.8 & 2.5 & 16.2 & 1.9 \\
\hline AL2723b & 53 & 240 & 316 & 4.1 & 4 & 86 & $\mathbf{P}$ & 4.6 & 2 & 12.2 & 1.3 \\
\hline AL2724 & 47 & 297 & 362 & 4.4 & 3.7 & 96 & $\mathbf{P}$ & 4.9 & 2.3 & 15.3 & 1.7 \\
\hline AL2725 & 47 & 285 & 309 & 3.8 & 2.1 & 95 & $\mathbf{P}$ & 4.7 & 2.4 & 17.3 & 2.1 \\
\hline AL2726 & 60 & 285 & 394 & 4.3 & 3 & 101 & $\mathbf{P}$ & 4.7 & 2.3 & 15.6 & 1.8 \\
\hline mean & 58 & 274 & 325 & 4.2 & 3.4 & 91 & & 4.5 & 2.2 & 15.6 & 1.8 \\
\hline Signif & NS & NS & NS & NS & NS & NS & & NS & NS & NS & NS \\
\hline
\end{tabular}

${ }^{1}$ scored 1 (poor) to 5 (near perfect); ${ }^{2}$ scored 1 (low) to 5 (high); ${ }^{3}$ root collar diameter; ${ }^{4} \mathrm{~V}=$ vegetative, $\mathrm{P}=$ pods (most frequent occurrence in bold); ${ }^{5}$ scored 1 (low) to 3 (high); final selections indicated by shading

those in Trial 2. Conversely, growth of lines in Trial 2 exceeded that of lines in Trial 1 for plant height (274 vs $168 \mathrm{~cm} ; \mathrm{P}<0.01$ ), plant width (325 vs $168 \mathrm{~cm} ; \mathrm{P}<0.01$ ), root collar diameter ( $91 \mathrm{vs} 58 \mathrm{~mm} ; \mathrm{P}<0.01$ ), and total plant DM (15.6 vs $6.7 \mathrm{~kg} /$ plant; $\mathrm{P}<0.05)$. There were no overall differences between trials in plant vigour in December and February, and mass of edible DM/plant.
Pods occurred on all plants of most lines in Trial 2 but on fewer plants of each line in Trial 1.

\section{Nitrogen content and digestibility}

Total N content of lines in Trial 2 was $25 \%$ higher than in Trial 1 (33 vs $26 \mathrm{~g} \mathrm{~N} / \mathrm{kg} \mathrm{DM}$; $\mathrm{P}<0.01$ ) but there was no significant variation between lines in each trial. In 
contrast, in vitro digestibility was similar $(\mathrm{P}>0.05)$ in both trials and for all lines, averaging $750 \mathrm{~g} \mathrm{DM} / \mathrm{kg}$ $\mathrm{DM}$, with a range of $730-800 \mathrm{~g} \mathrm{DM} / \mathrm{kg} \mathrm{DM}$.

\section{Discussion}

\section{Establishment and survival}

Rooted seedlings were used to establish the trials, which is an effective method to ensure relatively high productivity in the first 1-2 years (Frame et al. 1998). An alternative and cheaper option is direct seeding, particularly when hard seed content is reduced by appropriate scarification, seed is drilled rather than broadcast, and resident vegetation is reduced by strategic use of appropriate herbicides (Townsend \& Radcliffe 1987).

The major finding in this evaluation was the significant difference between plant survival and growth of lines at the two trial sites. Lower plant survival in Trial 2 than Trial 1 may have been owing to the occurrence of unseasonally severe frosts shortly after transplanting and at various times during the trial. Trial 2 was located on gently sloping land and it was found that after one year, plant survival at the lower end of the slope was less than at slightly higher elevation, again suggesting the influence of frost. Tagasaste is moderately susceptible to frost damage (Sheppard \& Bulloch 1986; Frame et al. 1998), particularly when young, and therefore needs to be planted at relatively frost-free sites for best results. The use of larger and more developed plants than used in this study, for example $50-80 \mathrm{~cm}$ high and multi-branched, coupled with extended periods of frost-hardening before transplanting, may confer increased plant tolerance to frosting in the field. Also, plants aged 1-2 years should not be defoliated in autumn, to avoid soft new regrowth being killed by frost.

Despite low to moderate plant survival of most tagasaste lines in Trial 2, similar levels have been recorded for the species in other studies, but probably for different reasons. For example Lambert et al. (1989a) found that after 3.5 years, $53 \%$ of plants of one line had survived at a summer-moist hill site in the lower North Island. The main factors influencing survival at that site were probably moderately acid soils ( $\mathrm{pH}$ 5.3), low plantavailable soil phosphate levels (Olsen $\mathrm{P}=4-8 \mathrm{mg} / \mathrm{kg}$ soil) and fungal collar rot disease arising from excessive soil moisture levels. None of these factors were regarded as important determinants of survival in the present evaluation because at both sites, Olsen P levels were very high, soil $\mathrm{pH}$ was approximately neutral, and soils were free-draining.

The relatively poor plant survival of most lines in Trial 2 was more than compensated for by surviving plants of each line producing more than twice the total DM yield of plants of those same lines in Trial 1. Hence there was a slight net advantage from growing tagasaste at the sandier Rangitikei site compared with the other site. However, within lines at each site, plant loss was not compensated for by increased yield of surviving plants. Despite the relatively large plants in Trial 2, they produced similar $(\mathrm{P}>0.05)$ total edible $\mathrm{DM}$ to those in Trial 1. Plants were not grazed in this evaluation but those in Trial 1 were less than $180 \mathrm{~cm}$ tall, and it is therefore likely that most edible foliage would have been accessible to sheep and particularly cattle. In contrast, all lines in Trial 2 exceeded $240 \mathrm{~cm}$ height which would have resulted in a relatively high proportion of edible foliage being above the height which could be reached by livestock. In this situation, particularly, harvesting by mechanical equipment or hand saw/ loppers, would be required to fully utilise the available edible foliage.

\section{Dry matter yield and quality}

The total plant yields achieved in this study, equivalent to 9-14 t DM/ha in Trial 1 and 18-36 t DM/ha in Trial 2 , were slightly higher than those reported elsewhere (Radcliffe 1985; Douglas et al. 1996). Although this may in part be owing to the evaluation of more productive material than previously, the most likely reason was that yield estimates were based on almost 2 years of growth, compared with earlier results which were obtained from about one year's regrowth following cutting. The lower proportion of edible foliage in the present study compared with the $40 \%$ found by Douglas et al. (1996) was also probably owing to age differences in the foliage harvested, since less frequently cut (older) foliage of tagasaste and numerous other shrub/tree species has significantly higher stem content (Lambert et al. 1989a).

The similar in vitro dry matter digestibility (DMD) for edible foliage of all lines across both trial sites (average $750 \mathrm{~g} / \mathrm{kg} \mathrm{DM}$ ) suggested that this attribute may be approximately constant over a range of environments where tagasaste might be grown. This was supported further by estimates obtained for different lines of tagasaste in other environments. For example $710-780 \mathrm{~g} / \mathrm{kg}$ DM in Canterbury (Borens \& Poppi $1990)$ and $710 \mathrm{~g} / \mathrm{kg} \mathrm{DM}$ on lower North Island hill country (Lambert et al. 1989b). Although N content of the lines varied between the two sites, it always exceeded $17 \mathrm{~g} / \mathrm{kg}$ DM which is the recommended level for an adequate diet for a lactating ewe with a single lamb (NRC 1975; Grace 1983).

Plants in Trial 2 had a significantly higher nonedible component of dry matter, including thicker trunks, than in Trial 1. Inedible stems of tagasaste burn with an 
intense heat when dry (Snook 1986) and the present results showed the potential of the species to produce potentially useful quantities of firewood in certain environments. The use of tagasaste for firewood is unlikely to be a major reason for its planting in New Zealand, but it is one of several uses for the species in addition to providing supplementary forage. Tagasaste is an important source of firewood internationally, especially in Africa.

\section{Selection for release}

On the basis of the results presented here, as well as other data from the evaluations at both sites, lines AL2244 and 2432 have been selected to form the final release. The dominant criterion used to select the two lines was high survival at both sites. However, numerous other morphological attributes were also considered and in every instance, AL2244 and AL2432 exceeded the average values for them. In earlier evaluations (Woodfield, unpubl.), line AL2244 ('Auchenflower') always had impressive growth habit and lack of foliar diseases, and its selection here supported the earlier findings. There was no evidence of collar or root rot disease of material in either trial, perhaps owing to the free-draining characteristics of both trial sites.

Seed is being collected from plants of each of the two lines at the original evaluation sites, following the cutting of all plants of the other lines to prevent flowering, and hence possible contamination of the selected material. There is uncertainty about tagasaste being predominantly self- or cross-pollinated. However, the consistency in growth and morphological development between plants within lines suggests that selfing was dominant in these trials. This will ensure relative genetic stability of the selection in successive cycles of seed multiplication.

Availability of the selection will provide pastoral farmers in drought-prone and frost-free environments with another source of supplementary forage for their livestock. Possible planting options for tagasaste are 1) the establishment of a feedbank and 2) widely spaced rows of the species with pasture in between.

\section{ACKNOWLEDGEMENTS}

This research was funded by the Foundation for Research, Science and Technology. We wish to thank D. Hocking (Bulls) and P. Catley (Onga Onga), who allowed us to use land on their properties.

\section{REFERENCES}

Borens, F.M.P.; Poppi, D.P. 1990. The nutritive value for ruminants of tagasaste (Chamaecytisus palmensis), a leguminous tree. Animal feed science and technology 28: 275-292.

Douglas, G.B.; Bulloch, B.T.; Foote, A.G. 1996. Cutting management of willows (Salix spp.) and leguminous shrubs for forage during summer. New Zealand journal of agricultural research 39: 175-184.

Frame, J.; Charlton, J.F.L.; Laidlaw, A.S. 1998. Temperate Forage Legumes, CAB International. Tagasaste: pp. 304-311.

Grace, N.D. 1983. The mineral requirements of grazing ruminants. Occasional publication no. 9, New Zealand Society of Animal Production: 150pp.

Lambert, M.G.; Jung, G.A.; Costall, D.A. 1989a. Forage shrubs in North Island hill country. 1. Forage production. New Zealand journal of agricultural research 32: 477-483.

Lambert, M.G.; Jung, G.A.; Harpster, H.W.; Budding, P.J.; Wewala, G.S. 1989b. Forage shrubs in North Island hill country. 3. Forage digestibility. New Zealand journal of agricultural research 32: 491-497.

McLeod, M.N.; Minson, D.J. 1976. The analytical and biological accuracy of estimating the dry matter digestibility of different legume species. Animal feed science and technology 1: 61-72.

McLeod, M.N.; Minson, D.J. 1980. A note on Onozuka $3 \mathrm{~S}$ cellulase as a replacement for Onozuka S 1500 cellulase when estimating forage digestibility in vitro. Animal feed science and technology 5: 347350.

NRC 1975. Nutrient requirements of sheep. National Academy of Sciences, Washington D.C. 72pp.

Radcliffe, J.E. 1985. Fodder tree production under cutting, for 5 years in Canterbury hill country. pp. 19-23. In: Fodder trees - a summary of current research in New Zealand. Logan, L.A.; Radcliffe, J.E. (eds) Crop Research Division, DSIR. Report No. 106.

SAS 1988. SAS user's guide, release 6.03 edition. Cary, North Carolina, USA: Statistical Analysis System Institute.

Sheppard, J.S.; Bulloch, B.T. 1986. Management and uses of Chamaecytisus palmensis (tree lucerne, tagasaste). pp. 194-198. In: Plant materials handbook for soil conservation, vol 2. Introduced plants, Technical note no. S3, van Kraayenoord, C.W.S.; Hathaway, R.L. (ed.) Water and Soil Miscellaneous Publication No. 94. Wellington: National Water and Soil Conservation Authority.

Snook, L.C. 1986. Tagasaste (tree lucerne), high production fodder crop. Shepparton, Australia: Night Owl Publishers.

Steel, R.G.D.; Torrie, J.H. 1980. Principles and procedures of statistics. A biometrical approach. Kogakusha: McGraw-Hill. 
Townsend, R.J.; Radcliffe, J.E. 1987. Establishment and management of tagasaste. Proceedings of the New Zealand Grassland Association. 48: 109-113. Woodfield, D.R.; Forde, M.B. 1987. Genetic variability within tagasaste. Proceedings of the New Zealand Grassland Association 48: 103-108. 